\title{
Geochemistry of surface sediments from the mid-oceanic Kolbeinsey Ridge, north of Iceland
}

\author{
K.S. Lackschewitz ${ }^{\text {a }}$, H.-J. Wallrabe-Adams ${ }^{\text {a }}$, D. Garbe-Schönberg ${ }^{\text {b }}$ \\ ${ }^{a}$ GEOMAR, Research Center for Marine Geosciences, Wischhofstraße 1-3, 24148 Kiel, Germany \\ ${ }^{b}$ Geologisch-Paläontologisches Institut und Museum der Universität Kiel, Olshausenstraße 40, 24098 Kiel, Germany
}

Received 30 January 1993; revision accepted 14 December 1993

\begin{abstract}
In order to assess recent submarine volcanic contributions to the sediments from the active Kolbeinsey Ridge, surface samples were analyzed chemically. The contribution of major and trace elements studied differ within the study area.

A statistical analysis of the geochemical variables using factor analysis and cluster method allows to distinguish possible sample groups. Cluster method identifies three distinct sediment groups located in different areas of sedimentation.

Group 1 is characterized by highest contents of $\mathrm{Fe}_{2} \mathrm{O}_{3}, \mathrm{~V}, \mathrm{Co}, \mathrm{Ni}, \mathrm{Cu}$ and $\mathrm{Zn}$ demonstrating the input of volcaniclastic material. Group 2 comprises high values of $\mathrm{CaCO}_{3}, \mathrm{CaO}$ and $\mathrm{Sr}$ representing biogenic carbonate. Group 3 is characterized by the elements $\mathrm{K}, \mathrm{Rb}, \mathrm{Cs}, \mathrm{La}$ and $\mathrm{Pb}$ indicating the terrigenous component.

The absolute percentage of the volcanic, biogenic and terrigenous components in the bulk sediments was calculated by using a normative sediment method. The highest volcanic component ( $>60 \%$ on a carbonate free basis) is found on the ridge crest. The biogenic component is highest $(10-30 \%)$ in the eastern part of the Spar Fracture Zone influenced by the East Iceland Current. Samples from the western and southeastern region of the study area contain more than $90 \%$ of terrigenous component which appears to be mainly controlled by input of ice-rafted debris.
\end{abstract}

\section{Introduction}

In the North Atlantic Ocean, the non-carbonate fraction of the sediments generally consists of detrital, contintental derived material. The contribution of the processes related to the volcanically active ridge on the surrounding pelagic sediments is not well known.

Data on geochemistry of the sediments from the Mid-Atlantic Ridge of the North Atlantic are well known from the TAG area at $26^{\circ} \mathrm{N}$ (Cronan, 1972; Rona, 1976; Cronan et al., 1979; Shearme et al., 1983).

For the Reykjanes Ridge in particular, the first geochemical data were published by Horowitz
(1974). Grousset et al. (1982) and Grousset and Chesselet (1986) gave information on geochemical characteristics of Late Quaternary marine sediments taken between the Azores and the Icelandic basin.

More recently, cores from the Greenland Sea including the Mohns Ridge were studied by Paetsch (1991), who showed the concentration variations of some elements with depth.

We have recently published preliminary results on the major and trace elements contents of the southern Kolbeinsey Ridge sediments (Lackschewitz and Wallrabe-Adams, 1991). The sedimentology of the surface samples from the Kolbeinsey Ridge were described in detail by 
Lackschewitz et al. (1991) and Lackschewitz (1991). Oehmig and Wallrabe-Adams (1993) have given data on the depositional environment using settling velocity experiments of volcaniclastic deposits from the southern Kolbeinsey Ridge.

The focus of this study is to identify and evaluate the portion of different sedimentary processes within the deposits from the Kolbeinsey Ridge to provide information about the recent sedimentary environment in the ridge area. Our study is placed on determining the geochemical variability of surface sediments from the vicinity of the active spreading ridge. Thus, we will attempt to identify geochemical parameters which function as indicators of characteristic sediment facies types using a "geochemical facial analysis". This allows to quantify the composition and spatial distribution of local enrichment and impoverishment of metals and to characterize the geochemical and facial conditions of sedimentation.

\section{Study area}

The Kolbeinsey Ridge is the section of the Mid-Atlantic Ridge north of Iceland beginning at about $66^{\circ} \mathrm{N}$ and extending northward to the Jan Mayen Fracture Zone near $71^{\circ} \mathrm{N}$. The southern Kolbeinsey Ridge is a recently active ridge segment (e.g. Spindler, 1989; Fricke et al., 1989).

The spreading velocity approximates $2 \mathrm{~cm} / \mathrm{yr}$ (Vogt, 1983).

The study area includes the southern part of the active spreading ridge between Iceland $\left(66^{\circ} 30^{\prime} \mathrm{N}\right)$ and the area of the Spar Fracture Zone $\left(69^{\circ} 30^{\prime} \mathrm{N}\right)$ (Fig. 1).

The main surface current system in the western Iceland Sea is characterized by the East Greenland Current which carries cold $\left(\angle 0^{\circ} \mathrm{C}\right)$ polar water southward along the East Greenland shelf (Fig. 1). The East Iceland Current in the central Iceland Sea $\left(0^{\circ}-4^{\circ} \mathrm{C}\right)$ forms a mixture of the polar and the warm Atlantic waters.

\section{Material and methods}

Sediment was collected by box coring during R.V. Poseidon cruise 158 and R.V. Polarstern cruise
ARK V/lb. Sampling and visual description of the surface sediments were carried out on board (Puteanus and Werner, 1989; Spindler, 1989). For the present study 25 surface samples recovered by box cores were selected.

A sample split was analyzed for the composition of its coarse fraction. The sediment samples were dried, weighed and washed on $63 \mu \mathrm{m}$ sieve. The particle association of the $125-500 \mu \mathrm{m}$ fraction seems to be most representative of coarse fraction composition. Thus, a split (>500 grains) of this size fraction was studied and counted for biogenic, terrigenous and volcanic components.

For major and trace element analysis, bulk sediment samples were oven-dried at $40^{\circ} \mathrm{C}$ and then pulverized. The major element composition was determined using a Philips (PW 1400) X-ray fluorescence spectrometer. For XRF analysis, the sediments were dried at $900^{\circ} \mathrm{C}$ and melted using lithiumtetraborate $\left(\mathrm{Li}_{2} \mathrm{~B}_{4} \mathrm{O}_{7}\right)$ in a mixture consisting of $1 \mathrm{~g}$ sediment and $4 \mathrm{~g}$ lithiumtetraborate. For calibration of the XRF determinations, 12 international rock standards were used. The trace elements were analyzed by ICP/MS using a VG Plasma-Quad PQ 1. Total dissolution of bulk sediment was performed by pressurized $\mathrm{HF}-\mathrm{HClO}_{4}$-aqua regia attack (Garbe-Schönberg, 1993). The accuracy of the analytical results was controlled by measuring the international standard reference material "MESS 1" (see Table 3).

Calcium carbonate contents were measured using a LECO CS-125 infrared analyzer. Both, total carbon (TC) and total organic carbon (TOC) contents were determined by infrared measurements of $\mathrm{CO}_{2}$ absorption. Organic carbon was calculated from $\mathrm{CO}_{2}$ that was released by treatment with hydrochloric acid. The calcium carbonate content was calculated in weight percentages of sediment sample as:

$\mathrm{CaCO}_{3} \%=(\mathrm{TC} \%-\mathrm{TOC} \%) \times 8.33$

The percentage of $\mathrm{Ca}$ on a carbonate-free basis is also given in Table 1 as $\mathrm{CaO}_{\text {silicate }}$. The content of $\mathrm{CaO}_{\text {silicate }}$ in the sediment was calculated by subtracting $\mathrm{CaO}_{\text {carbonate }}\left(0.5604 \mathrm{CaCO}_{3}\right)$ from $\mathrm{CaO}_{\text {bulk }}$ and assuming that the difference comprised only $\mathrm{Ca}_{\text {silicate }}$. 


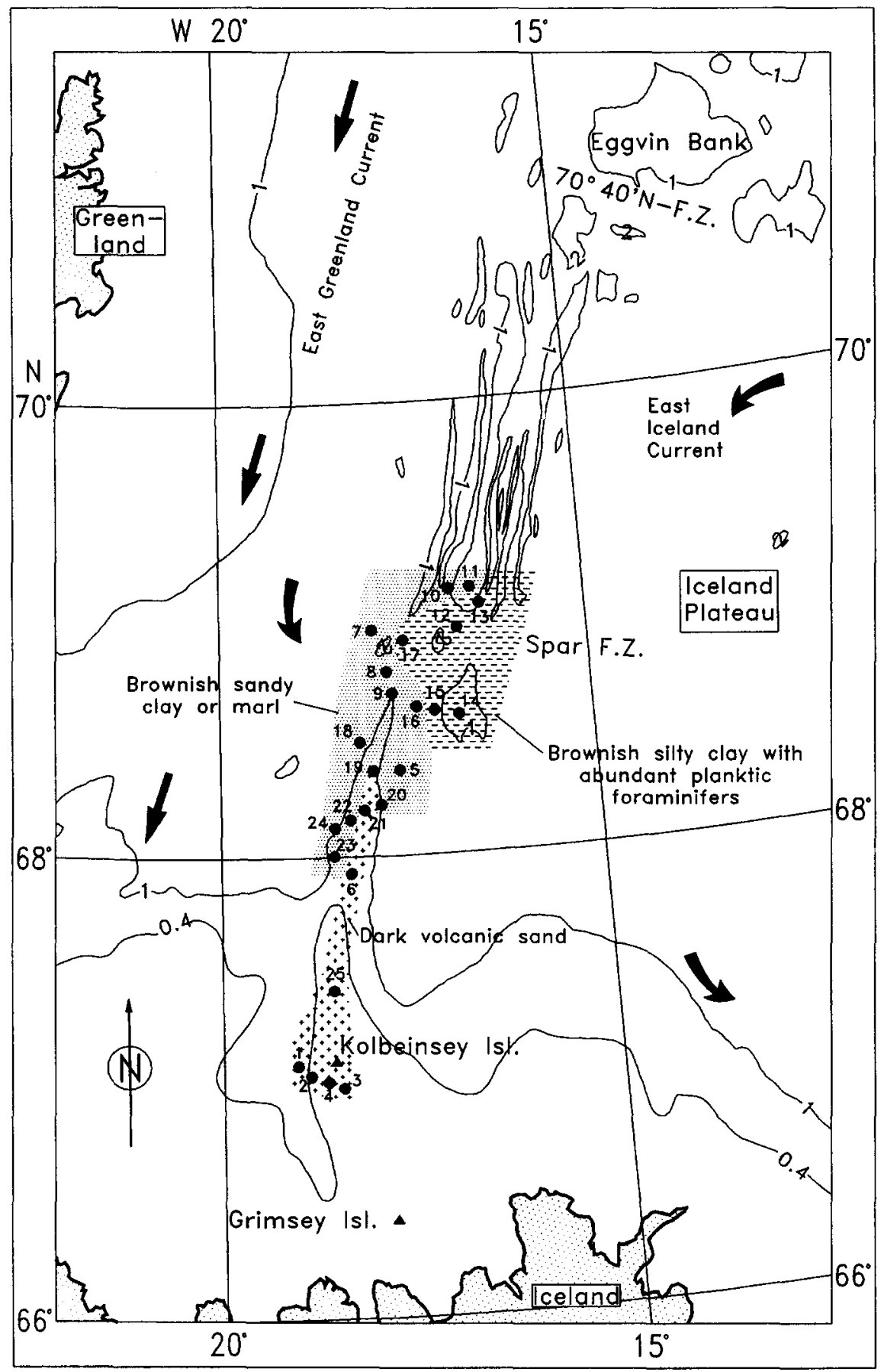

Fig. 1. Study area, lithology and location of surface samples in the Iceland Sea. 
Table 1

Geochemical composition of basaltic glass from volcaniclastic sediments and from "zero age" basalts from Kolbeinsey Ridge

\begin{tabular}{ll}
$\begin{array}{l}\text { Basaltic glass } \\
\text { Kolbeinsey Ridge } \\
\text { (Lackschewitz and }\end{array}$ & $\begin{array}{l}\text { Average basaltic rocks } \\
\text { Kolbeinsey Ridge } \\
\text { (Devey et al., 1994) }\end{array}$ \\
1991 ) & \\
\hline 50.6 & \\
1.19 & 50.2 \\
13.3 & 0.98 \\
13.0 & 14.5 \\
0.20 & 12.9 \\
7.60 & 0.21 \\
11.7 & 7.76 \\
1.72 & 11.9 \\
0.07 & 1.83 \\
& 0.07 \\
& 225 \\
& 59 \\
& 105 \\
& 124 \\
& 95 \\
\end{tabular}

\section{Results and discussion}

\subsection{Surface sediment description and composition}

Surface sediments from the basin west and east of the Kolbeinsey Ridge generally consist of brownish sandy silty clay (Fig. 1). The sand fraction of these sediments is mainly composed of terrigenous particles and small amounts of biogenic material. The terrigenous particle assemblages consist mainly of quartz and sedimentary and crystalline rock fragments.

East and northeast of the Spar Fracture Zone sediments are characterized by sandy silty clay with relatively high concentrations of planktic foraminifers. Generally, in all surface samples the fauna is made up of the subpolar species Neogloboquadrina pachyderma (sinistral). The temperate species $N$. pachyderma (dextral), which indicates warmer water masses were only observed in the samples east and northeast of the Spar Fracture Zone. The foraminifers are normally well preserved. Siliceous biogenic particles (mostly sponge spicules) are usually less than 2 weight $-\%$ (wt.-\%). A higher content in siliceous particles
(4.3-10.7 wt.- $\%$ ) was observed in the surface sediments $10 / 2,19 / 1,20 / 1$ and $21 / 1$.

The most drastic changes in lithology occur on the southern Kolbeinsey Ridge. Here, sediments show an increase in the amount and size of dark volcanic sand (Fig. 1). These sediments consist of dark brown volcanic glass and dark volcanic rock fragments. The volcanic material is mostly fresh. The average major and trace element composition of the basaltic glass is given in Table 1. For comparison, the composition of basaltic rocks from Kolbeinsey Ridge are also shown (Devey et al., 1994). Some palagonitized glasses, fragments of volcanic rocks weathered in various degrees are only found in the southernmost samples near the Kolbeinsey Island.

\subsection{Distribution of major and trace element concentration in the surface sediments}

The percentages of major and trace elements are given in Tables 2 and 3. The statistical parameters are reported in Table 4.

Silicon ( $\mathrm{Si}$ ) is the dominant major element found in the sediments studied. For the western and northern portions of the study area mean $\mathrm{SiO}_{2}$ values were approximately $60 \%$. Highest $\mathrm{SiO}_{2}$ values $(70.5-72.7 \%)$ were observed in surface sediments taken in the vicinity of the Spar Fracture Zone. By contrast, sediments from the southern section of the study area have an average concentration of only $57 \%$. Lowest $\mathrm{SiO}_{2}$ values of $51-53 \%$ were determined in surface sediments from the ridge crest area. These sediments are also characterized by extremely low values of $\mathrm{K}_{2} \mathrm{O}(<0.8 \%)$. Sediments from the central Kolbeinsey Ridge have the highest concentrations of $\mathrm{Fe}_{2} \mathrm{O}_{3}(11.4-14.6 \%)$, Co (43-52 ppm), V (223-384 ppm) and $\mathrm{Cu}$ (71$107 \mathrm{ppm})$. Increased concentrations of $\mathrm{CaO}_{\text {silicate }}$ of $9-11.6 \%$ were also observed here. The content of $\mathrm{CaCO}_{3}$ is generally very low $(<2 \%)$ in the ridge crest sediments.

The highest $\mathrm{CaCO}_{3}$ concentrations (10-28.5\%) are found in surface sediments from the eastern part of the Spar Fracture Zone area and further north. Also, the highest concentrations of $\mathrm{Sr}$ with up to $680 \mathrm{ppm}$ were found in these sediments.

The carbonate in the sediments is tied to tests 
Table 2

Major element oxide concentrations in surface sediments in $\%$

\begin{tabular}{|c|c|c|c|c|c|c|c|c|c|c|c|c|c|}
\hline Sample & Core & $\mathrm{SiO}_{2}$ & $\mathrm{TiO}_{2}$ & $\mathrm{Al}_{2} \mathrm{O}_{3}$ & $\mathrm{Fe}_{2} \mathrm{O}_{3}$ & $\mathrm{MnO}$ & $\mathrm{MgO}$ & $\mathrm{CaO}$ & $\mathrm{Na}_{2} \mathrm{O}$ & $\mathrm{K}_{2} \mathrm{O}$ & Sum & $\mathrm{CaCO}_{3}$ & ${ }^{*} \mathrm{CaO}$ silicate \\
\hline 1 & $13 / 015$ & 52.0 & 0.36 & 12.4 & 12.8 & 0.19 & 9.76 & 10.9 & 1.29 & 0.30 & 100.0 & 0.18 & 10.8 \\
\hline 2 & $13 / 016$ & 53.1 & 0.53 & 12.4 & 12.8 & 0.16 & 8.80 & 9.46 & 1.43 & 0.74 & 99.4 & 0.78 & 9.02 \\
\hline 3 & $13 / 018$ & 52.6 & 0.31 & 12.1 & 12.7 & 0.17 & 9.40 & 10.1 & 1.38 & 0.57 & 99.3 & 0.25 & 9.96 \\
\hline 4 & $13 / 019$ & 50.8 & 0.41 & 13.0 & 11.4 & 0.14 & 10.6 & 12.3 & 1.07 & 0.19 & 99.9 & 1.17 & 11.6 \\
\hline 5 & $0001 / 1$ & 62.2 & 1.20 & 15.2 & 8.53 & 0.25 & 2.93 & 4.99 & 2.22 & 2.36 & 100.3 & 3.63 & 2.96 \\
\hline 6 & $0002 / 2$ & 52.7 & 1.26 & 13.6 & 13.5 & 0.24 & 5.95 & 10.8 & 1.89 & 0.53 & 100.7 & 2.54 & 9.38 \\
\hline 7 & $0003 / 1$ & 71.3 & 0.74 & 11.7 & 5.17 & 0.16 & 1.96 & 6.32 & 1.65 & 2.06 & 101.1 & 7.13 & 2.33 \\
\hline 8 & $0004 / 1$ & 70.5 & 0.73 & 11.6 & 5.13 & 0.16 & 1.93 & 6.28 & 1.80 & 2.16 & 100.3 & 7.17 & 2.26 \\
\hline 9 & $0005 / 1$ & 68.7 & 0.89 & 11.3 & 6.08 & 0.16 & 2.36 & 6.12 & 1.78 & 1.93 & 99.3 & 5.78 & 2.88 \\
\hline 10 & $0006 / 1$ & 63.5 & 0.94 & 13.7 & 6.68 & 0.22 & 2.27 & 7.75 & 2.38 & 2.45 & 100.1 & 9.22 & 2.59 \\
\hline 11 & $0007 / 1$ & 57.7 & 0.98 & 13.2 & 7.30 & 0.18 & 2.50 & 13.9 & 1.59 & 2.24 & 99.1 & 14.7 & 2.67 \\
\hline 12 & $0008 / 1$ & 63.0 & 0.70 & 10.8 & 5.61 & 0.13 & 2.68 & 13.3 & 1.56 & 1.57 & 99.5 & 18.0 & 3.20 \\
\hline 13 & $0009 / 1$ & 64.4 & 0.79 & 11.6 & 5.47 & 0.18 & 1.96 & 11.5 & 1.57 & 2.12 & 99.5 & 13.4 & 4.00 \\
\hline 14 & $0010 / 2$ & 51.4 & 0.89 & 13.0 & 7.19 & 0.34 & 2.31 & 20.2 & 1.28 & 2.19 & 99.1 & 28.5 & 4.20 \\
\hline 15 & $0011 / 1$ & 61.9 & 1.11 & 12.9 & 7.44 & 0.20 & 2.51 & 9.30 & 1.96 & 2.00 & 99.4 & 10.2 & 3.59 \\
\hline 16 & $0012 / 1$ & 68.1 & 0.88 & 12.3 & 6.44 & 0.18 & 2.35 & 5.50 & 1.85 & 2.14 & 99.7 & 5.05 & 2.67 \\
\hline 17 & $0013 / 1$ & 54.2 & 1.23 & 12.7 & 8.13 & 0.19 & 2.96 & 16.8 & 2.25 & 1.83 & 100.4 & 26.9 & 1.70 \\
\hline 18 & $0015 / 1$ & 67.0 & 0.96 & 13.0 & 7.21 & 0.17 & 2.65 & 5.19 & 1.74 & 2.19 & 100.1 & 5.50 & 2.11 \\
\hline 19 & $0016 / 1$ & 52.3 & 1.11 & 13.5 & 13.4 & 0.21 & 7.03 & 11.1 & 1.98 & 0.27 & 100.0 & 3.30 & 9.25 \\
\hline 20 & $0017 / 1$ & 72.7 & 0.84 & 10.2 & 5.98 & 0.13 & 2.34 & 4.27 & 1.54 & 1.84 & 100.2 & 2.51 & 2.86 \\
\hline 21 & $0018 / 1$ & 50.8 & 1.16 & 13.6 & 14.6 & 0.22 & 6.94 & 11.0 & 2.01 & 0.12 & 100.4 & 2.83 & 9.42 \\
\hline 22 & $0019 / 1$ & 62.3 & 1.27 & 12.4 & 8.62 & 0.23 & 2.94 & 8.01 & 1.90 & 1.61 & 99.3 & 5.42 & 4.97 \\
\hline 23 & $0020 / 1$ & 66.2 & 1.23 & 12.7 & 8.10 & 0.21 & 2.93 & 4.77 & 2.25 & 1.85 & 100.2 & 0.66 & 4.40 \\
\hline 24 & $0021 / 1$ & 63.1 & 1.34 & 14.5 & 9.30 & 0.37 & 3.13 & 4.16 & 2.11 & 2.11 & 100.1 & 0.95 & 3.63 \\
\hline 25 & $0023 / 1$ & 50.9 & 1.10 & 13.3 & 13.2 & 0.21 & 6.94 & 11.1 & 1.83 & 0.18 & 98.9 & 0.37 & 10.9 \\
\hline
\end{tabular}

${ }^{*} \mathrm{CaO}_{\text {silicate }}=\mathrm{CaO}_{\text {bulk }}-\mathrm{CaO}_{\text {carbonate }} ; \mathrm{CaO}_{\text {carbonate }}=0.5604 \mathrm{CaCO}_{3}$.

of calcareous foraminifers and coccoliths. These tests consist of low-magnesium calcite.

\subsection{Statistical analysis}

The results show distinct regional variations in the chemical composition of surface sediments. An interpretation of these results, however, is dependent on a clarification of the complex chemical conditions and on a classification of the surface sediments. Following this, a factor analysis of all available samples will make it possible to distinguish significant variations of individual parameters. These variations will be interpreted in terms of distinct facies types and sedimentary processes, respectively.

Cluster analysis was applied to find homogenous sample groups on the basis of the chemical composition of the surface sediments. These analyses will permit us to quantify the composition and distribution of different sedimentary facies.

The surface sediments of the Kolbeinsey Ridge are characterized by four factors which explain $87.7 \%$ of variance (Fig. 2 ).

Factor 1 (36.3\% of the variance) has loadings of $\mathrm{Al}_{2} \mathrm{O}_{3}, \mathrm{Fe}_{2} \mathrm{O}_{3}, \mathrm{MgO}, \mathrm{MnO}, \mathrm{V}, \mathrm{Co}, \mathrm{Ni}, \mathrm{Cu}$ and $\mathrm{Zn}$ and a somewhat lower loadirg of $\mathrm{TiO}_{2}$. This factor is believed to represent dark volcanic glass and/or dark volcanic rock fragments. These elements are characteristic of mafic minerals. Thus, high levels of $\mathrm{Fe}_{2} \mathrm{O}_{3}, \mathrm{MgO}, \mathrm{Co}, \mathrm{Cu}$ and $\mathrm{V}$, with high percentages of volcanic material, are found in sediments on the central ridge. Lackschewitz and Wallrabe-Adams (1991) exhibit that increased concentrations of $\mathrm{Fe}_{2} \mathrm{O}_{3}, \mathrm{MgO}, \mathrm{Co}, \mathrm{Ni}, \mathrm{Cu}$ and $\mathrm{Zn}$ are indicators of submarine glass particles from sediments of the southernmost Kolbeinsey Ridge and Devey et al. (1994) take these to be 
Table 3

Trace element concentrations in surface sediments in ppm. "MESS 1" is an international reference standard repeatedly analyzed during the ICP-MS analytical runs for controlling the accuracy of the analytical results

\begin{tabular}{|c|c|c|c|c|c|c|c|c|c|c|c|c|}
\hline Sample & Core & V & $\mathrm{Co}$ & $\mathrm{Cu}$ & $\mathrm{Ni}$ & $\mathrm{Zn}$ & $\mathrm{Rb}$ & $\mathrm{Sr}$ & Mo & $\mathrm{Cs}$ & $\mathrm{La}$ & $\mathrm{Pb}$ \\
\hline 1 & $13 / 015$ & 253 & 45 & 92 & 55 & 93 & 13 & 104 & n.d. & n.d. & n.d. & 5 \\
\hline 2 & $13 / 016$ & 252 & 43 & 85 & 52 & 99 & 21 & 146 & n.d. & n.d. & n.d. & 7 \\
\hline 3 & $13 / 018$ & 244 & 43 & 71 & 60 & 100 & 18 & 100 & n.d. & n.d. & n.d. & 8 \\
\hline 4 & $13 / 019$ & 223 & 52 & 97 & 82 & 96 & n.d. & 84 & n.d. & n.d. & n.d. & 6 \\
\hline 5 & $0001 / 1$ & 200 & 26.7 & 38.5 & 44.7 & 106 & 93.2 & 314 & 1.84 & 4.87 & 37.8 & 31.9 \\
\hline 6 & $0002 / 2$ & 336 & 45.8 & 85.8 & 46.4 & 107 & 15.2 & 151 & 0.96 & 0.83 & 8.8 & 15.1 \\
\hline 7 & $0003 / 1$ & 119 & 18.1 & 22.7 & 28.2 & 69.7 & 64.5 & 244 & 1.72 & 2.91 & 25.5 & 18.6 \\
\hline 8 & $0004 / 1$ & 114 & 16.7 & 25.7 & 34.3 & 59.8 & 66.0 & 237 & 2.06 & 2.58 & 25.5 & 20.0 \\
\hline 9 & $0005 / 1$ & 135 & 18.8 & 29.1 & 29.9 & 77.6 & 57.9 & 236 & 1.09 & 2.42 & 23.2 & 19.9 \\
\hline 10 & $0006 / 1$ & 152 & 22.4 & 24.8 & 35.4 & 97.4 & 88.7 & 334 & 2.08 & 4.03 & 35.5 & 27.5 \\
\hline 11 & $0007 / 1$ & 144 & 20.9 & 36.4 & 35.0 & 74.2 & 65.7 & 379 & 1.10 & 3.80 & 28.1 & 22.2 \\
\hline 12 & $0008 / 1$ & 146 & 19.8 & 21.4 & 38.1 & 85.8 & 45.2 & 337 & 1.11 & 1.80 & 18.4 & 17.9 \\
\hline 13 & $0009 / 1$ & 126 & 17.3 & 23.4 & 30.2 & 69.5 & 64.4 & 373 & 1.06 & 2.92 & 25.3 & 21.7 \\
\hline 14 & $0010 / 2$ & 158 & 28.6 & 29.8 & 31.3 & 96.1 & 70.0 & 678 & 2.20 & 4.25 & 29.4 & 26.6 \\
\hline 15 & $0011 / 1$ & 175 & 23.1 & 35.5 & 32.0 & 88.6 & 61.7 & 313 & 1.86 & 2.95 & 25.3 & 19.8 \\
\hline 16 & $0012 / 1$ & 149 & 20.9 & 33.9 & 45.9 & n.d. & 66.4 & 237 & 1.89 & 3.18 & 28.8 & 27.6 \\
\hline 17 & $0013 / 1$ & 112 & 16.0 & 19.7 & 26.1 & 58.1 & 53.3 & 566 & 0.98 & 2.68 & 21.8 & 21.3 \\
\hline 18 & $0015 / 1$ & 219 & 21.5 & 34.2 & 36.0 & 91.8 & 69.4 & 261 & 1.66 & 3.23 & 28.6 & 24.1 \\
\hline 19 & $0016 / 1$ & 357 & 45.1 & 78.7 & 58.7 & 106 & 15.5 & 154 & 1.61 & 0.69 & 9.8 & 11.0 \\
\hline 20 & $0017 / 1$ & 149 & 20.4 & 35.8 & 35.8 & 76.5 & 52.7 & 214 & 0.95 & 1.98 & 21.8 & 24.4 \\
\hline 21 & $0018 / 1$ & 310 & 44.4 & 71.0 & 55.7 & 112 & 23.6 & 170 & 1.14 & 0.92 & 12.0 & 16.8 \\
\hline 22 & $0019 / 1$ & 199 & 26.1 & 50.5 & 39.7 & 107 & 46.7 & 290 & 1.90 & 2.37 & 24.4 & 40.3 \\
\hline 23 & $0020 / 1$ & 173 & 24.0 & 42.3 & 35.2 & 98 & 49.5 & 198 & 1.55 & 2.25 & 26.3 & 29.2 \\
\hline 24 & $0021 / 1$ & 434 & 56.5 & 91.5 & 92.6 & 216 & 132 & 415 & 4.37 & 6.63 & 57.9 & 55.9 \\
\hline 25 & $0023 / 1$ & 384 & 51.5 & 107 & 69.9 & 545 & 5.9 & 93 & 1.12 & 0.15 & 4.0 & 6.9 \\
\hline \multirow{2}{*}{\multicolumn{2}{|c|}{$\begin{array}{l}\text { MESS } 1 \\
\text { this work by } \\
\text { ICP-MS }(n=4)\end{array}$}} & 72.4 & 16.8 & 25.1 & 29.5 & 191 & 100 & 89.0 & 2.2 & 4.0 & 30.0 & 34.0 \\
\hline & & 65.2 & 14.3 & 25.4 & 28.4 & 177 & 92.7 & 87.6 & 2.5 & 4.3 & 35.6 & 31.2 \\
\hline \multicolumn{2}{|c|}{ SD } & 2.6 & 0.4 & 0.7 & 1.0 & 4.8 & 2.5 & 2.7 & 0.1 & 0.1 & 2.0 & 0.5 \\
\hline
\end{tabular}

n.d. $=$ no data. $\mathrm{SD}=$ standard deviation.

indicators of basalts from the Kolbeinsey Ridge (see Table 1).

Factor 2 (26.2\% of variance) shows high negative loadings of $\mathrm{K}_{2} \mathrm{O}, \mathrm{Rb}, \mathrm{Mo}, \mathrm{Cs}$, La and somewhat lower negative loadings for $\mathrm{Sr}$ and $\mathrm{Pb}$. Here, the high rate of deposition of clay minerals and feldspars is reflected in the sediments. $\mathrm{Rb}$ and $\mathrm{Cs}$ are primarily absorbed by detritic, potassium-rich minerals such as illite and orthoclase (Wedepohl, 1969). Grousset et al. (1982) demonstrate a correlation between $\mathrm{Rb}$ and the clay minerals illite, kaolinite and chlorite within sediments from the North Atlantic and from the southern NorwegianGreenland Sea. $\mathrm{K}$ and $\mathrm{Rb}$ are generally bound to the acidic lithogenic component in sediments from the Norwegian-Greenland Sea (Paetsch, 1991).

All these parameters designate factor 2 as a detrital factor.

Factor 3 (11.3\% of variance) displays a high loading of $\mathrm{CaO}$ and somewhat lower loadings of $\mathrm{CaCO}_{3}$ and Sr. Turekian (1964) showed a frequent correlation between $\mathrm{Sr}$ and biogenic $\mathrm{CaCO}_{3}$. During the formation of $\mathrm{CaCO}_{3} \mathrm{Sr}$ is extracted from the surface water and inserted in the carbonate shell material due to its crystallochemical similarity to the carbonate phase(Broecker and Peng, 1982). These positive loadings represent biogenic carbonate. 
Table 4

Statistical parameters for major and trace elements

\begin{tabular}{|c|c|c|c|c|}
\hline Variable & Average* & $\mathrm{SD}$ & Minimum* & Maximum* \\
\hline $\mathrm{CaCO}_{3}$ & 7.10 & 7.63 & 0.18 & 28.5 \\
\hline $\mathrm{C}_{\text {org }}$ & 0.53 & 0.23 & 0.07 & 1.16 \\
\hline $\mathrm{SiO}_{2}$ & 60.1 & 7.30 & 50.8 & 72.7 \\
\hline $\mathrm{TiO}_{2}$ & 0.92 & 0.29 & 0.31 & 1.34 \\
\hline $\mathrm{Al}_{2} \mathrm{O}_{3}$ & 12.7 & 1.09 & 10.2 & 15.2 \\
\hline $\mathrm{Fe}_{2} \mathrm{O}_{3}$ & 8.92 & 3.06 & 5.13 & 14.6 \\
\hline $\mathrm{MnO}$ & 0.20 & 0.06 & 0.13 & 0.37 \\
\hline $\mathrm{MgO}$ & 4.33 & 2.81 & 1.93 & 10.6 \\
\hline $\mathrm{CaO}$ & 9.40 & 3.97 & 4.16 & 20.2 \\
\hline $\mathrm{K}_{2} \mathrm{O}$ & 1.50 & 0.81 & 0.12 & 2.45 \\
\hline $\mathrm{Na}_{2} \mathrm{O}$ & 1.77 & 0.33 & 1.07 & 2.38 \\
\hline V & 211 & 88.9 & 112 & 434 \\
\hline Co & 30.7 & 13.1 & 16.0 & 56.5 \\
\hline $\mathrm{Ni}$ & 45.2 & 16.8 & 26.1 & 92.6 \\
\hline $\mathrm{Cu}$ & 51.3 & 28.1 & 19.7 & 107 \\
\hline $\mathrm{Zn}$ & 114 & 94.6 & 58.1 & 545 \\
\hline $\mathrm{Rb}$ & 51.0 & 29.5 & 5.90 & 132 \\
\hline Sr & 265 & 141 & 84.0 & 678 \\
\hline Mo & 1.63 & 0.74 & 0.95 & 4.37 \\
\hline Cs & 2.74 & 1.47 & 0.15 & 6.63 \\
\hline $\mathrm{La}$ & 24.7 & 11.1 & 4.04 & 57.9 \\
\hline $\mathrm{Pb}$ & 19.1 & 12.4 & 0.54 & 55.9 \\
\hline
\end{tabular}

*Major element concentration in \%; trace element concentration in ppm.

The factor 4 (13.9\% of variance) has high negative loadings of $\mathrm{C}_{\text {org }}, \mathrm{Na}_{2} \mathrm{O}$ and $\mathrm{Pb}$. This factor is believed to represent an organic component. We can't explain the meaning of $\mathrm{TiO}_{2}$ in this factor.

\subsection{Cluster analysis}

The result of the cluster analysis is shown by the dendrogram in Fig. 3. Three groups of samples are visible.

With respect to average concentrations in all samples studied, group 1 is characterized by highest contents of $\mathrm{Fe}_{2} \mathrm{O}_{3}, \mathrm{MgO}, \mathrm{V}, \mathrm{Co}$ and $\mathrm{Cu}$. The concentration of $\mathrm{CaCO}_{3}$ and $\mathrm{K}_{2} \mathrm{O}$ are lower. The other elements are close to the arithmetic mean from total data base (Table 4). A comparison with factor 1 , which documents the volcaniclastic facies, points to a connection of the group with this factor.

Group 2 contains the samples with the highest values of $\mathrm{CaCO}_{3}, \mathrm{CaO}$ and $\mathrm{Sr}$ in the surface sediment, thus demonstrating the high loading of geochemical parameters of the carbonate factor 3 .
The lowest $\mathrm{Fe}_{2} \mathrm{O}_{3}$ values are found in the samples from this group. As a result of the diluting effect of carbonate, the elements or element oxides $\mathrm{TiO}_{2}$, $\mathrm{Al}_{2} \mathrm{O}_{3}, \mathrm{MgO}, \mathrm{V}, \mathrm{Co}, \mathrm{Ni}, \mathrm{Cu}$ and $\mathrm{Zn}$ are also relatively diluted and lie below the mean values of the total data base (Table 3).

Most samples were grouped together in group 3 , which is characterized by a heterogeneity of all parameter with the exception of generally lower $\mathrm{CaO}$ values. Mean values for the individual elements/element oxides of this group were compared with the respective average values of the total data base for the purpose of further characterization. The mean values for $\mathrm{TiO}_{2}, \mathrm{Fe}_{2} \mathrm{O}_{3}, \mathrm{MgO}, \mathrm{CaO}, \mathrm{V}$, $\mathrm{Co}, \mathrm{Cu}, \mathrm{Zn}$ and $\mathrm{Sr}$ lie below the average values. In this group the mean values of $\mathrm{Rb}, \mathrm{Cs}, \mathrm{La}$ and $\mathrm{Pb}$ are highest and correspond to the detritic factor 2 .

\subsection{Normative analysis}

A quantification of individual characteristic sediment components in the bulk sediment is essential for an estimate of submarine volcanic activity on the Kolbeinsey Ridge.

Bischoff et al. (1979) and Dymond (1981) calculated the absolute percentage of various components in the bulk sediment using normative sediment models. An assessment of biogenic, lithogenic and hydrothermal components was carried out by Metz et al. (1988) using calcium carbonate and aluminium data.

Factor analysis permits only qualitative estimates of the distribution of sediment components. For quantitative estimates, other methods have been developed. An overall balance of surface sediments on the Kolbeinsey Ridge was drawn up here in accordance with the methods developed by Metz et al. (1988).

To calculate the percentage of biogenic, terrigenous and volcanic components in the bulk sediment, we used weight percentages (wt. $-\%$ ) of siliceous biogenic particles, wt.- $\% \mathrm{CaCO}_{3}$ and wt. $\% \mathrm{~K}_{2} \mathrm{O}$ data.

Since, according to sedimentological studies, $\mathrm{C}_{\text {org }}$ and siliceous biogenic particles combined generally make up $<2 \%$ of the total sediment, the biogenic content was equated with the $\mathrm{CaCO}_{3}$ 

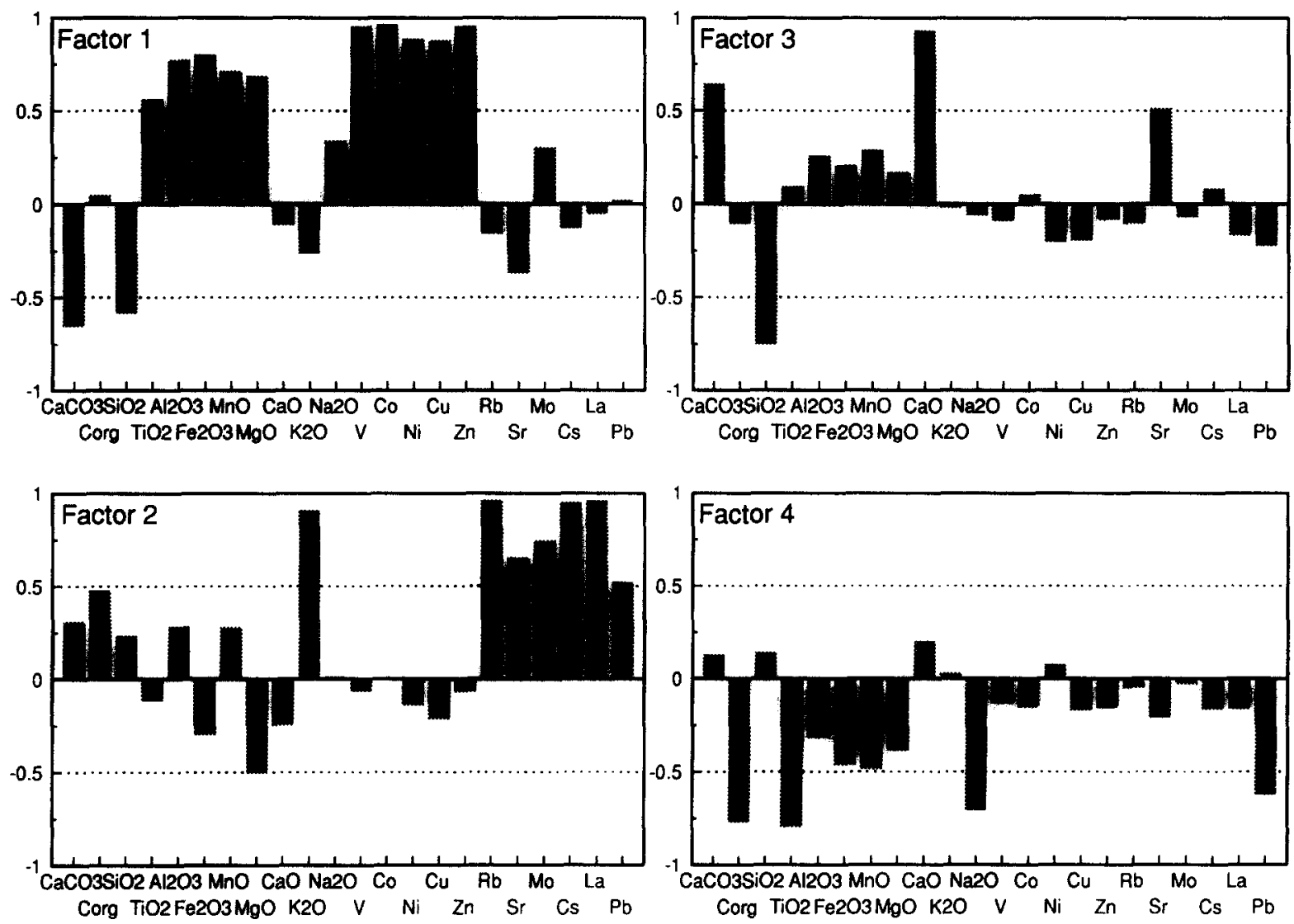

Fig. 2. Rotated factor loadings and varimax factor scores.

content of the surface sediments. An exception are the surface sediments $(10 / 2,19 / 1,20 / 1$ and $21 / 1)$ which show markedly higher percentages of siliceous biogenic particles. The biogenic content of these samples is computed using the equation:

$$
\begin{aligned}
\% \text { biogenic component }= & \text { wt. }-\%{ }^{\mathrm{CaCO} 3} \\
& +\mathrm{wt} .-\% \%_{\text {siliceous biogenic particles }}
\end{aligned}
$$

In the volcanic group, the terrigenous content can be calculated on the basis of the $\mathrm{K}_{2} \mathrm{O}$ concentration in the bulk sediment, provided that the entire $\mathrm{K}_{2} \mathrm{O}$ is bound to terrigenous material.

The potassium content in carbonate sediments is nearly exclusively bound to the non-carbonate fraction (Wedepohl, 1969). Bowen (1966) describes no detectable potassium concentrations for calcareous foraminifers, calcareous sponges, corals, molluscs and echinoderms recording a mean potassium content of $5.8 \mathrm{ppm}$ for siliceous sponges.

The average $\mathrm{K}_{2} \mathrm{O}$ content for "zero age" basaltic components from the Kolbeinsey Ridge is $0.07 \%$ (Lackschewitz and Wallrabe-Adams, 1991; Devey et al., 1994).

The $\mathrm{K}_{2} \mathrm{O}$ of clayey sediments is primarily bound to clay minerals, potassium feldspars and mica, although mica generally has a high correlation with clay mineral content (Welby, 1958). Weaver (1965) reports high concentrations of potassium in illites. Chester (1965) records an average $\mathrm{K}_{2} \mathrm{O}$ of $2.3 \%$ for pelagic deep-sea sediments.

For this reason, nearly the entire concentration of $\mathrm{K}_{2} \mathrm{O}$ in our surface samples from the volcanic group must be traced back to the terrigenous content. The $\mathrm{K}_{2} \mathrm{O}$ content was first determined from the non-carbonate fraction of the surface 


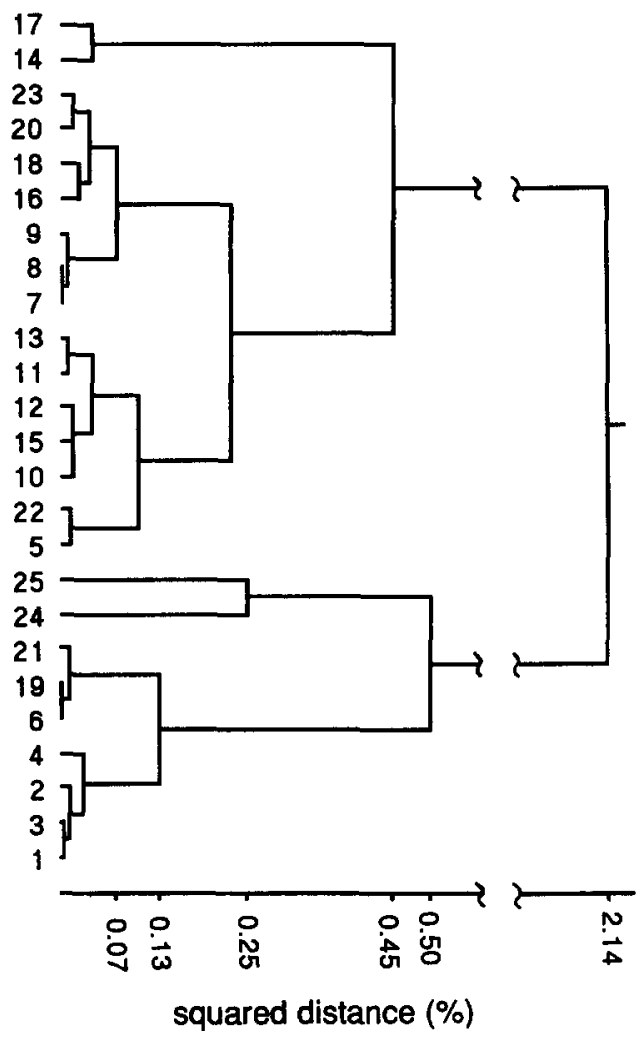

Fig. 3. Dendrogram from cluster analysis (Tanimoto distance, Ward's method) of geochemical data. Dendrogram sample numbers are identical to Table 2.

samples in the terrigenous group. The arithmetic mean of potassium in this group is $2.2 \%$. Generally, this value is in good agreement with the average $\mathrm{K}_{2} \mathrm{O}$ of $2.3 \%$ for pelagic deep-sea sediments.

On the basis of the calculated average $\mathrm{K}_{2} \mathrm{O}$ content, the percentage of the terrigenous component was calculated for the samples in the volcanic group as follows:

$$
\begin{aligned}
& \%_{\text {terrigenous component }}= \\
& \qquad \frac{(100 \%-\% \text { biogenic component }) \times \mathrm{K}_{2} \mathrm{O}_{\text {volcanic }}}{2.2 \%}
\end{aligned}
$$

Thus, the volcanic content can be calculated using:

$$
\begin{aligned}
\% \text { volcanic component }= & 100 \%-\% o_{\text {terrigenous component }} \\
& -\% \%_{\text {biogenic component }}
\end{aligned}
$$

\subsection{Distribution of the biogenic, terrigenous and volcanic components}

The distribution of volcanic, terrigenous and biogenic sediment components in surface sediments is shown in Figs. 4-6.

The highest percentages ( $>60 \%$ ) of the volcanic component occur in the vicinity of the ridge crest. This pattern shows a marked similarity with the lithology presented in Fig. 1. These sediments obviously derived from submarine volcanism which produce lava flows, volcanic glass, and volcanic rock fragments. An indication of hydrothermal activity along the Kolbeinsey Ridge is only documented near Kolbeinsey Island showing boiling water and shaking basalt fragments caused by gas bubbles (Fricke et al., 1989). Generally, the terrigenous and the biogenic component is relatively low in the area of the ridge crest reflecting enhanced dilution by volcaniclastic material. Sediments with still abundant volcanic material but a large amount of terrigenous component are also found in samples from the adjacent ocean floor. According to Lackschewitz and Wallrabe-Adams (1991) and Oehmig and Wallrabe-Adams (1993), bottom currents and mass flows are responsible for downslope transport of volcanic material.

The regional distribution of the biogenic component in the western Iceland Sea is shown in Fig. 5. The highest percentages of the biogenic sediment component ( $20-30 \%)$ have been determined in the eastern and northeastern area of the Spar Fracture Zone, whereas this component decreases significantly to the west. According to the normative analysis calcium carbonate is the best indicator for the biogenic component (foraminifers and coccoliths). Bulk calcium carbonate contents of surface samples provide a good approximation to differentiate surface water masses in the Iceland Sea (Baumann et al., 1993). The amounts of planktic foraminifers and coccolithophorids are found in samples from the East Iceland water masses indicating a relatively high calcium carbonate shell production (Samtleben and Schröder, 1992). In contrast, low production of $\mathrm{CaCO}_{3}$ towards the Greenland continental margin can be related to the polar water masses of the East 


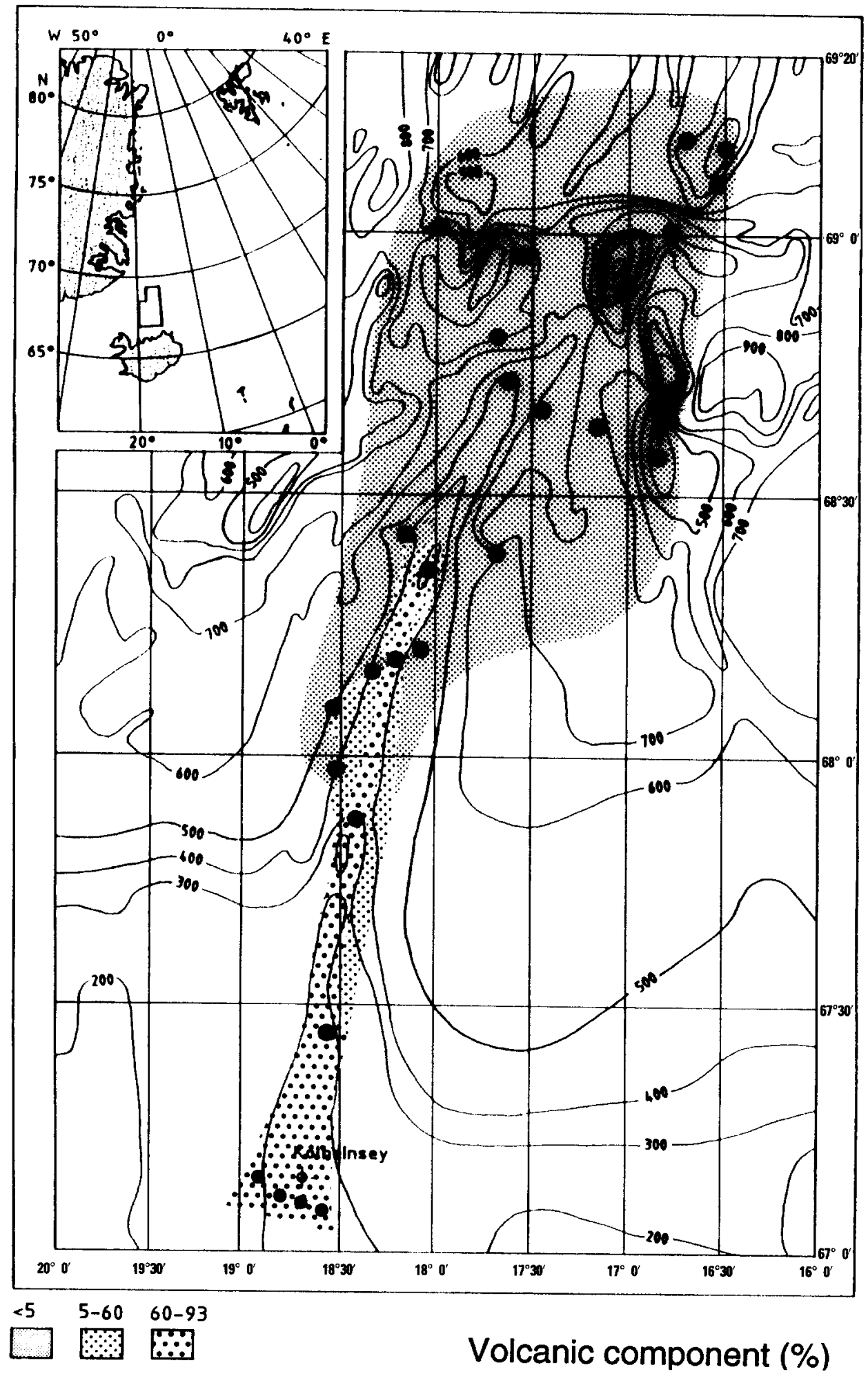

Fig. 4. Distribution and percentages of the volcanic component on the basis of normative sediment analysis. 


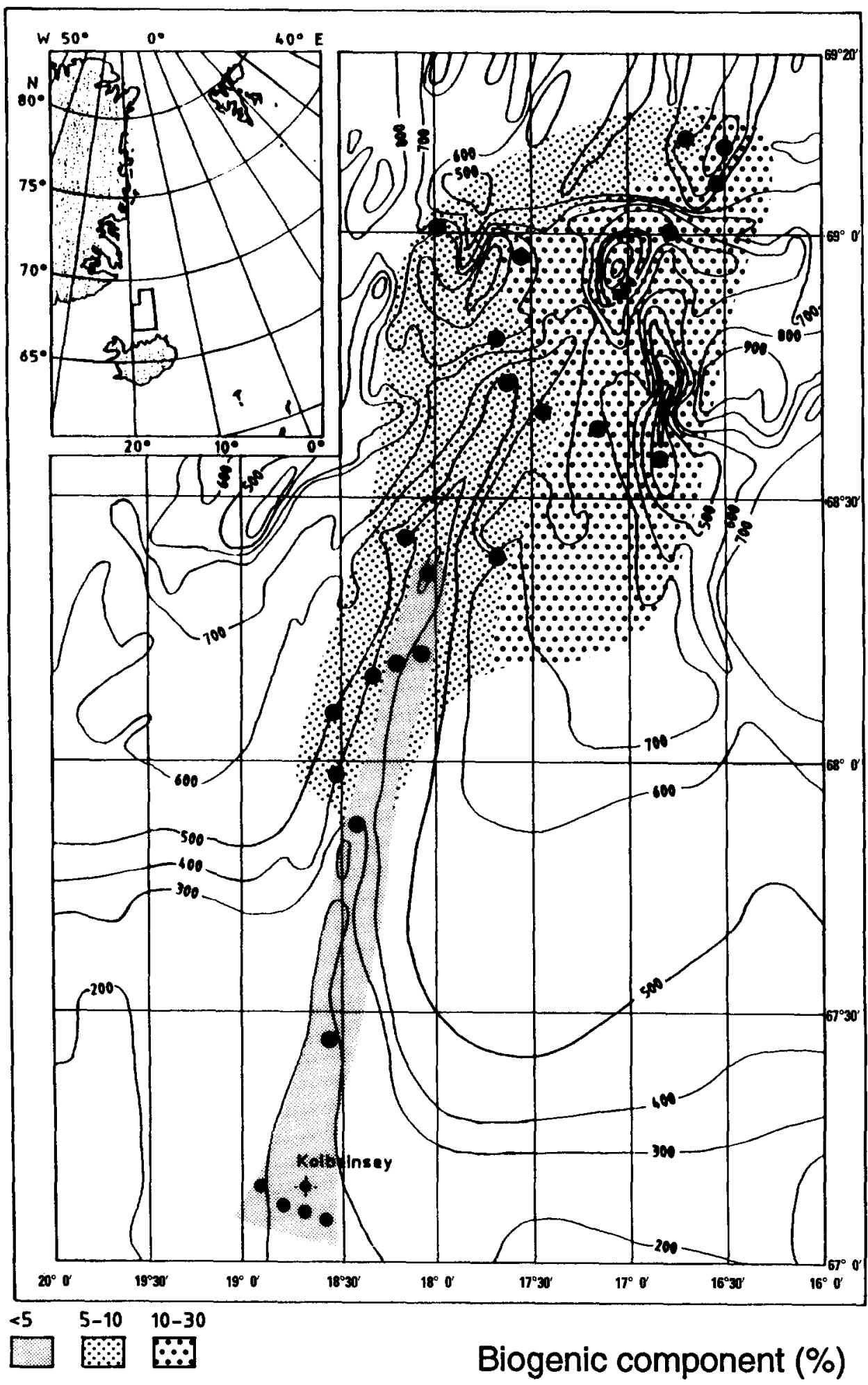

Fig. 5. Distribution and percentages of the biogenic component on the basis of normative sediment analysis. 


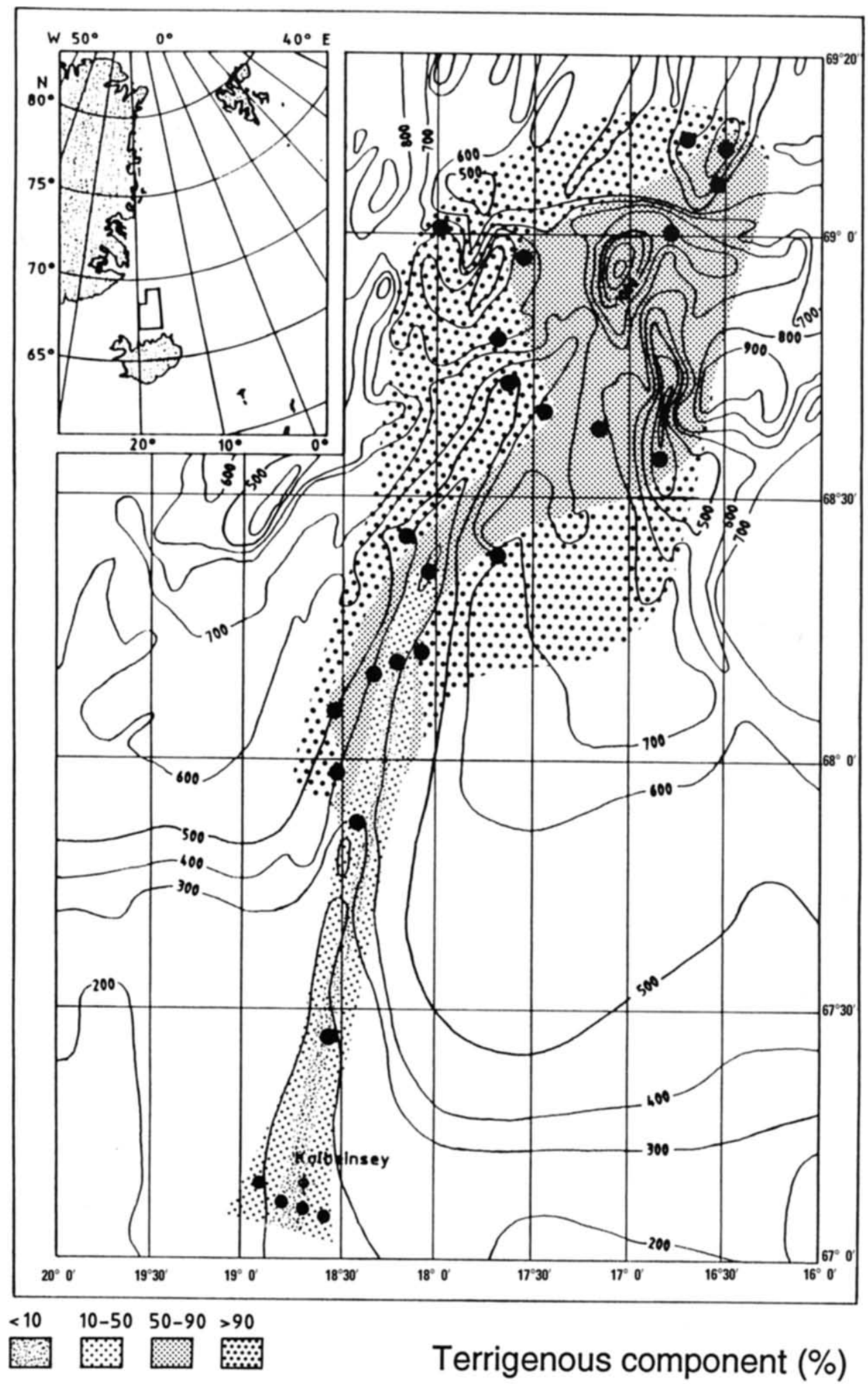

Fig. 6. Distribution and percentages of the terrigenous component on the basis of normative sediment analysis. 
Greenland Current. Thus, the relatively high amounts of $\mathrm{CaCO}_{3}$ in surface sediments east of the Kolbeinsey Ridge are probably caused by a higher production in the East Iceland Current influenced by warmer Atlantic water masses.

Generally, our results are in good agreement with the data of Peatsch et al. (1992) and Baumann et al. (1993).

In addition, a distinct increase in $\mathrm{Sr}$ concentrations is observed in relation with relatively high calcium carbonate contents reaching the sediment over the calcium carbonate production. Cornblad and Malmgren (1981) show that the incorporation of $\mathrm{Sr}$ into the carbonate shells of planktic foraminifers correlate positively with the surface water temperature.

Fig. 6 shows the amount of the terrigenous sediment component. Generally, the surface sediments in the west and southeast of the study area exhibit $90 \%$ of the terrigenous component. These sediments are characterized by highest concentrations of $\mathrm{K}_{2} \mathrm{O}$ and $\mathrm{Rb}$. Grousset and Chesselet (1986) note an increase in $\mathrm{Rb}$ towards the Greenland continent. The main source of the metals in the marine sediments near the continent seems to be weathered terrestial material from Greenland. The transport mechanism for this material cannot be determined clearly owing to its geographical distribution. Grain size distribution shows no pattern of turbidity current or contour current activity. But previous studies of marine sediments from the high latitudes have shown that the high amounts of coarse terrigenous particles $(>63 \mu \mathrm{m})$ in the Norwegian-Greenland Sea can be interpreted as ice-rafted material (Bischof, 1990; Henrich, 1990; Spielhagen, 1991). Enhanced deposition of ice-rafted detritus indicate that extensive melting of ice occurs in this area. Because sea ice sediments are mostly fine-grained and contain little or no terrigenous grains $>63 \mu \mathrm{m}$ (Pfirman et al., 1989a,b; Wollenburg, 1993), icebergs from land and fjord glaciers are proposed as transport agents for the bulk of the sand-sized terrigenous material (Molnia, 1972; Clark and Hanson, 1983). In addition, input of clayey and/or silty terrigenous material in the NorwegianGreenland Sea can be caused by density currents from the continental shelfs (Elverhøi et al., 1989; Blaume, 1992). A drastic decrease in the terrigenous component was observed on the ridge crest indicating increased dilution by volcanic material.

In summary, the area of the mid-oceanic Kolbeinsey Ridge monitors the interaction between the terrigenous sediment input, submarine volcanic processes and the biogenic particle production (Fig. 7).

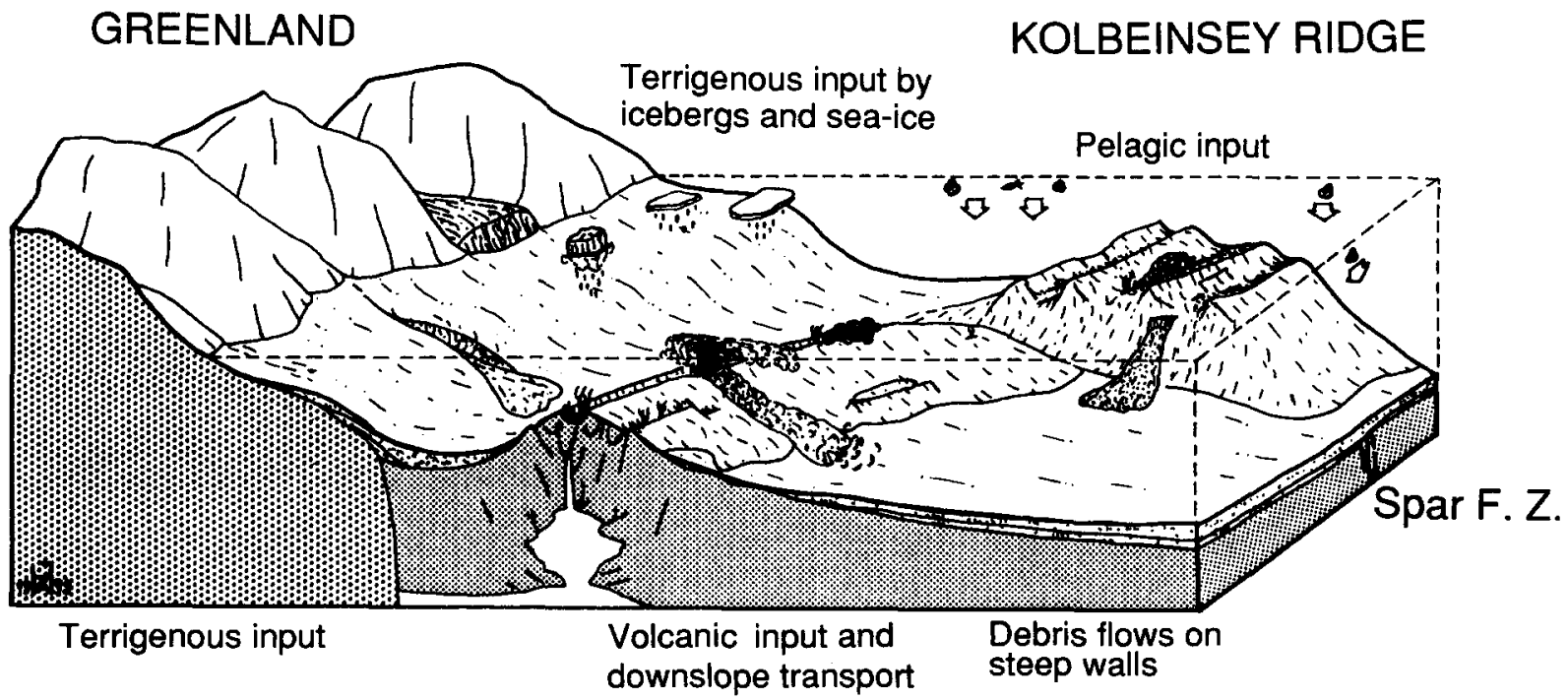

Fig. 7. Scheme of the recent sedimentation processes in the area of the Kolbeinsey Ridge. 


\section{Conclusions}

High compositional gradients in sediments between Iceland and Jan Mayen result from a variability in sedimentary sources of different geographic regions.

Bulk chemical composition in surface sediments and normative sediment analysis allow quantitative estimates of three distinct components:

(1) a volcanic component;

(2) a terrigenous component; and

(3) a biogenic component.

A straightforward approach to calculating the terrigenous contribution to the sediments was made using calcium carbonate and $\mathrm{K}_{2} \mathrm{O}$ data.

The terrigenous component is generally $>90 \%$ in basins lying west and east of the Kolbeinsey Ridge presumably caused by deposition of terrigenous debris into regions with small contributions from other sources. The terrigenous facies is defined by the association of the elements $K, R b$, $\mathrm{Cs}, \mathrm{La}$ and $\mathrm{Pb}$.

$\mathrm{Fe}, \mathrm{V}, \mathrm{Co}, \mathrm{Ni}, \mathrm{Cu}$ and $\mathrm{Zn}$ are the elements analyzed that most strongly reflect the volcanic input. Highest volcanic deposition is recorded in surface sediments from the ridge crest containing 60 to $90 \%$ of this component. This range indicates that submarine volcanic activity has had a substantial influence on sedimentation in the region.

The distribution of the biogenic component indicated by the content of calcium carbonate reflects the importance of warmer Atlantic water masses east of the Spar Fracture Zone.

\section{Acknowledgements}

We thank J. Thiede for supervising the project. We gratefully acknowledge two anonymous reviewers for their critical discussion and valuable comments. Thanks are due to P. Stoffers for access to the ICP/MS and to C. Devey to operate the $\mathrm{X}$-ray fluorescence spectrometer. For technical assistance, we thank H.-C. Reimers. C. Hoffmann and $\mathrm{J}$. Welling corrected the English. We also thank Capt. Andresen and his crew of the R.V. Poseidon on cruise 158 and Capt. Greve and his crew of the R.V. Polarstern on cruise ARK V/1.
This investigation forms part of the research project "The Greenland-Scotland-Ridge" and was funded by the Bundesministerium für Forschung und Technologie (Grant MFG 00664).

\section{References}

Baumann, K.-H., Lackschewitz, K.S., Erlenkeuser, H., Henrich, H. and Jünger, B., 1993. Late Quaternary calcium carbonate sedimentation and terrigenous input along the East Greenland continental margin. Mar. Geol., 114: 13-36.

Bischof, J., 1990. Dropstones in the Norwegian-Greenland Sea - Indications of a late Quaternary circulation pattern? In: U. Bleil and J. Thiede (Editors), Geologic History of the Polar Oceans: Arctic versus Antartic. (NATO ASI Ser. C, 308.) Kluwer, Dordrecht, pp. 499-518.

Bischoff, J.L., Heath, G.R. and Leinen, M., 1979. Nature and origin of metalliferous sediments in DOMES site C, Pacific Manganese Nodule Province, In: J.L. Bischoff and D.Z. Piper (Editors), Marine Geology and Oceanography of the Pacific Manganese Nodule Province. Plenum, New York, pp. 397-436.

Blaume, F., 1992. Hochakkumulationsgebiete am norwegischen Kontinentalhang: Sedimentologische Abbilder Topographiegeführter Strömungsmuster. Ber. Sonderforschungsber. 313, Univ. Kiel, 36: 1-150.

Bowen, H.J.M., 1966. Trace Elements in Biochemistry. Academic Press, New York.

Broecker, W.S. and Peng, T.H., 1982. Tracers in the Sea. Columbia Univ., $690 \mathrm{pp}$.

Chester, R., 1965. Elemental geochemistry of marine sediments. In: J.P. Riley and G. Skirrow (Editors), Chemical Oceanography. 2: 23-80.

Clark, D.L. and Hanson, A., 1983. Central Artic Ocean sediment texture: a key to ice transport mechanism, In: B.F. Molnia (Editor), Glacial-marine Sedimentation. Plenum, New York, pp. 301-330.

Cronan, D.S., 1972. The Mid-Atlantic Ridge near $45^{\circ} \mathrm{N}$, XVII: $\mathrm{Al}, \mathrm{As}, \mathrm{Hg}$ and $\mathrm{Mn}$ in ferruginous sediments from the Median Valley. Can. J. Earth Sci., 9: 319-323.

Cronan, D.S., Rona, P.A. and Shearme, S., 1979. Metal enrichments in sediments from the TAG Hydrothermal Field. Mar. Mining, 2: 79-89.

Cronblad, H.G. and Malmgren, B.A., 1981. Climatically controlled variation of $\mathrm{Sr}$ and $\mathrm{Mg}$ in Quaternary planktonic foraminifera. Nature, 291: 61-64.

Devey, C.W., Garbe-Schönberg, D., Stoffers, P., Chauvel, C. and Mertz, D.F., 1994. Chemical effects of dynamic melting beneath ridges: reconciling major and trace element variations in Kolbeinsey (and global) MORB. J. Geophys. Res., 99 (B5): 9077-9095.

Dymond, J., 1981. Geochemistry of Nazca Plate surface sediments: An evaluation of hydrothermal, biogenic, detrital 
and hydrogenous sources. Geol. Soc. Am. Mem., 154: 133-173.

Elverhøi, A., Pfirman, S.L., Solheim, A. and Larssen, B.B, 1989. Glaciomarine sedimentation in epicontinental seas exemplified by the Northern Barents Sea. Mar. Geol., 85: 225-250.

Fricke, H., Giere, O., Stetter, K., Alfredsson, G.A., Kristjansson, J.K., Stoffers, P. and Svavarsson, J., 1989. Hydrothermal vent communities at the shallow subpolar Mid-Atlantic Ridge. Mar. Biol., 102: 425-429.

Garbe-Schönberg, D., 1993. Simultaneous determination of 37 trace elements in 28 international rock standards by ICP/MS. Geostandards Newslett., 17: 81-97.

Grousset, F.E. and Chesselet, R., 1986. The Holocene sedimentary regime in the northern Mid-Atlantic Ridge region. Earth Planet. Sci. Lett., 78: 271-287.

Grousset, F., Latouche, C. and Parra, M., 1982. Late Quaternary sedimentation between Gibbs Fracture and the Greenland Basin: Mineralogical and geochemical data. Mar. Geol., 47: 303-330.

Henrich, R., 1990. Cycles, rhythms, and events in Quaternary Arctic and Antarctic glaciomarine deposits. In: U. Bleil and J. Thiede (Editors), Geologic History of the Polar Oceans: Arctic versus Antarctic. (NATO ASI Ser. C, 308.) Kluwer, Dordrecht, pp. 213-244.

Horowitz, A., 1974. The geochemistry of sediments from the northern Reykjanes Ridge and the Iceland-Faeroes Ridge. Mar. Geol., 17: 103-122.

Lackschewitz, K.S., 1991. Sedimentationsprozesse am aktiven mittelozeanischen Kolbeinsey Rücken (nördlich von Island. Geomar Rep., 9: 1-133.

Lackschewitz, K.S. and Wallrabe-Adams, H.-J., 1991. Composition and origin of sediments on the mid-oceanic Kolbeinsey Ridge, north of Iceland. In: T.O. Vorren, $\mathbf{H}$. Sejrup and J. Thiede (Editors), Cenozoic Geology of the Northwest European continental margin and adjacent deep sea areas. Mar. Geol., 101: 71-82.

Lackschewitz, K.S., Oehmig, R. and Wallrabe-Adams, H.-J., 1991. Der aktive mittelozeanische Rücken als Sedimentationsraum-Zusammensetzung und Dynamik der Sedimente am Kolbeinsey-Rücken (N Island). Zbl. Geol. Paläontol., Part I, 1990: 1727-1738.

Metz, S., Trefry, J.H. and Nelsen, T.A., 1988. History and geochemistry of a metalliferous sediment core from MidAtlantic Ridge at $26^{\circ} \mathrm{N}$. Geochim. Cosmochim. Acta, 52: 2369-2378.

Molnia, B.F., 1972. Pleistocene ice rafting in the North Atlantic Ocean. Ph.D. Thesis, Columbia, Univ. South Carolina. (Unpubl.)

Oehmig, R. and Wallrabe-Adams, H.-J., 1993. Hydrodynamic properties and grain size characteristics of volcaniclastic deposits on the Mid-Atlantic Ridge north of Iceland (Kolbeinsey Ridge). J. Sediment. Petrol., 63: 140-151.

Paetsch, H., 1991. Sedimentation im Europåischen Nordmeer: Radioisotopische, geochemische und tonmineralogische Untersuchungen spätquartärer Ablagerungen. Ber. Sonderforschungsbereich 313, 29: 1-83.

Paetsch, H., Botz, R., Scholten, J.C. and Stoffers, P., 1992. Accumulation rates of surface sediments in the NorwegianGreenland Sea. Mar. Geol., 104: 19-30.

Pfirman, S.L. and Solheim, A., 1989. Subglacial meltwater discharge in the open-marine tidewater glacier environment; observations from Nordaustlandet, Svalbard archipelago. Mar. Geol., 86: 265-281.

Pfirman, S., Wollenburg, I. and Thiede, J., 1989. Lithogenic sediment on Arctic pack ice: Potential aelian flux and contribution to deep sea sediments. In: M. Leinen and M. Sarnthein (Editors), Paleoclimatology and Paleometeorology: Modern and Past Patterns of Global Atmospheric Transport. Nato ASI Ser. C, 282: 463-493.

Puteanus, D. and Werner, F., 1990. Bericht über Reise Nr. 158 des F.S. Poseidon in das Seegebiet um Island. Ber. Geol.-Palăontol. Inst. Mus. Christian-Albrechts-Univ. Kiel, 38.

Rona, P.A., 1976. Pattern of hydrothermal mineral deposits: Mid-Atlantic Ridge crest at lat. $26^{\circ}$ N. Mar. Geol., 21: M59-M66.

Samtleben, C. and Schröder, A., 1992. Living coccolithophore communities in the Norwegian-Greenland Sea and their record in sediments. Mar. Micropaleontol., 19: 333-354.

Shearme, S., Cronan, D.S. and P.A. Rona, 1983. Geochemistry of sediments from the TAG Hydrothermal Field, M.A.R. at latitude $26^{\circ} \mathrm{N}$. Mar. Geol., 51: 269-291.

Spielhagen, R.F., 1991. Die Eisdrift in der Framstra $\beta$ e während der letzten 200,000 Jahre. Geomar Rep., 4: 1-133.

Spindler, M., 1989. The expeditions ARKTIS V/1a, 1b and 2 of RV "Polarstern" 1988. Rep. Polar Res., 59: 1989.

Turekian, K.K., 1964. The marine geochemistry of strontium. Geochim. Cosmochim. Acta, 28: 1479-1496.

Vogt, P.R., 1983. The Iceland mantle plume: Status of the hypothesis after a decade of new work. In: M.H.P. Bott, S. Saxov, M. Talwani and J. Thiede (Editors), Structure and Development of the Greenland-Scotland Ridge. (Nato Conf. Ser. IV, 8.) Plenum, New York, pp. 191-213.

Weaver, C.E., 1965. Trace Elements in Biochemistry. Academic Press, New York.

Wedepohl, K.H., 1969. Handbook of Geochemistry. Springer, Berlin.

Welby, C.W., 1958. Occurrence of alkali metals in some Gulf of Mexico sediments. J. Sediment. Petrol., 28: 431-452.

Wollenburg, I., 1993. Sedimenttransport durch das arktische Meereis-Die rezente lithogene und biogene Materialfracht. Ber. Polarforsch., 127: 1-159. 